\title{
Internet
}

\section{Jump-Starting Your Library Research Online}

\section{Sherri Chasin Calvo}

Want to save some time in your library research? How about cutting out some of the time you spend getting to the library, looking for parking and change for the meter ... then looking for the book or journal you need and hearing it's at another library on another campus ... and then starting the process all over again? A good way is to do as much research online as possible, before you ever leave your office.

Where to start? Today's bricks-and-mortar libraries have Internet sites, even if they are of varying degrees of usefulness. In general, the most useful sites for you will be those at the libraries where you have borrowing privileges. That's because some of the library's services, especially access to proprietary databases for which the library has paid license fees, are usually restricted to those who have a valid library-user number. Often, this number appears on the library card with a bar code.

A good public library system is a valuable resource. Many libraries grant cards to those who work in the community as well as to those who live there. This is useful if you work in a big city but live in the suburbs. Increasing numbers of public library systems have placed their catalogs online and have included status information about which branches have the item in question and whether or not it is on the shelf. Often, you can make reserve or interlibrary loan requests using e-mail or a Web-based form.

Public libraries that belong to larger consortia have more resources to offer. In Maryland, a system called Sailor links all the library systems within the state. Here, users can access a Gale Group database product called Infotrac (http://infotrac.galegroup.com/itweb/sailor_main) by typing in a valid user number from any Maryland public library system. Sailor offers access to a Health Reference Center database where searches can be limited to academic, professional or publications of general interest. Other databases available through Sailor include the General Reference Center Gold, which indexes magazines and references books, and a newspaper index. Infotrac and comparable databases offered by other publishers are available using many other library systems, as well.

Of course, university libraries are generally the venue of choice for serious research. Again, borrowing privileges are key to getting the best service online, just as in person. If you are affiliated with a university, you probably have a library card. If not, there are usually ways to obtain at least a subset of the privileges provided to faculty, staff and students. Some university libraries make their privileges available for a fee. Alumni members can usually get a library card also. If you have an opportunity to keep a computer account at the university, it may be worthwhile to do so, because some services are offered only from within the university's Internet domain.

The basic functions provided through university library Web sites, including catalog searches, reserve requests and database access, are similar to those offered by public libraries. However, the content is broader and deeper and includes journals and abstracts as well as books, magazines and newspapers. You can also save much time by finding out in advance and with a single search which of the university's campus or departmental libraries holds the book or journal you want.

The typical university library system offers access to hundreds of online databases. In the life sciences alone, for example, the University of Maryland library Web site

(http://victorweb.lib.umd.edu:9000/) has gateways to the following:

- BIOSIS Previews (an index to articles in over 6000 life sciences journals)

- Cambridge Scientific Abstracts (Biomedical and Life Sciences Collection, Environmental Sciences Collection)

- CHID (Combined Health Information Database)

- CINAHL (Cumulative Index of Nursing and Allied Health Literature)

- Health Reference Center

- Journal Citation Reports on the Web

- MEDLINE (Freely available at a number of sites on the Web, this site offers information about articles related to medicine found in more than 5000 medical and basic science journals.)

- OMIM (Online Mendelian Inheritance in Man; genetic diseases and heritable conditions)

- Science Citation Index Expanded ${ }^{\circledR}$ (an index to articles in over 5000 major science journals)

- TOXLINE (an index to articles on toxic chemicals)

In addition, important multidisciplinary databases are available, including a number of general periodical indexes and PapersFirst for conference proceedings.

The Web sites of medical school libraries can be particularly useful. Harvard Medical School's Countway Library offers several online journal subscriptions, a few of which can be accessed from off-site. The library also subscribes to many databases. A directory at http://www.countway. med.harvard.edu/databases/ clearly states the requirements for accessing each one. Freely available databases include the MEDLINE group, as well as Physician Data Query (PDQ), the Whole Brain Atlas, World Health News and resources on Alzheimer's disease, biotechnology and traumatic stress. With a Harvard ID number, dozens more are available.

Veterinary libraries fill the same role for researchers who are interested primarily in animal science. At Tufts University's Webster Veterinary Library, a Veterinary Research Workstation (http://www.library.tufts.edu/vet/vrw/index. html) offers students, faculty and staff online access to Cambridge Scientific's Aquatic Science \& Fisheries, Oceanic Abstracts and a variety of additional databases. Links to an impressive number of journals' Web sites are provided, from African Wildlife Update to Veterinary Pathology. An extensive Virtual Reference Collection includes a well-chosen set of links to important online resources at other sites. 


\section{Internet On-Ramp}

In many cases, you can carry out your literature search over the Internet to find out where to get the journal you need, but you still have to go physically to the library and pull it off the shelf. However, this too is starting to change. As journals begin to go electronic, they often make online full-text access available. The Journal of the American Medical Association (www.ama-assn.org) and The New England Journal of Medicine (http://www.nejm.org/) are both freely available via the Web. Other journals offer their tables of contents, but restrict online access to subscribers. Since no one can subscribe to all the journals relevant to their field, as a patron of the library, you can often access online journals to which the library has a subscription. Some libraries require a user to be on the premises to get electronic access, though this rather defeats the purpose. It is hoped that such policies will change over time.

A good way to avoid both a trip to the library and hefty subscription fees is to use pay-per-view services. These are most often provided from the Web site of the journal itself. For about $\$ 5.00$ charged to your VISA or MasterCard, you can receive the article you need either via the Web, email or fax. Increasing numbers of journals are providing this capability.

One of the most useful university-based "virtual library" services is offered by Stanford University through its Highwire Press (http://www.highwire.org/). As Stanford's "Internet imprint", Highwire assists in the publication of hundreds of online journals in life sciences and other fields. Using its site, it is possible to search these journals, individually or collectively. About 150000 articles are freely available in full text, and many more are accessible on a pay-per-view basis.

Freely available to everyone-and especially valuable if you don't have a university affiliation-are the online library resources of the US government. The Library of Congress (http://www.loc.gov/) offers access not only to its own catalog but also to those of over 300 other libraries all over the world. Materials may be requested through your own public or university library via interlibrary loan.

The Library of Congress includes only limited holdings in the fields of clinical medicine and agriculture, as there are other government libraries committed to serving these areas. The National Library of Medicine (http://www.nlm. nih.gov/), part of the National Institutes of Health, is the creator of MEDLINE, an indispensable online resource. This database includes about 11 million references, many with abstracts. About 400 of the more than 5000 indexed journals provide full-text retrieval capabilities. Alternatively, documents may be ordered through a service called Loansome Doc.

Two interfaces to the MEDLINE database are offered through the National Library of Medicine (NLM) site. The PubMed interface (http://www.ncbi.nIm.nih.gov/

PubMed/) has a simple search mechanism in which the user enters keywords and receives a list of matching citations. In PubMed's advanced search option, searches can be restricted to subsets of the database, such as nursing or dentistry journals, or to citations with abstracts. Search aids include a journal browser, thesaurus, citation matcher and a clinical query capability with a research methodology filter that allows a researcher to choose from the categories of therapy, diagnosis, etiology and prognosis, and then select for emphasis on sensitivity or specificity. PubMed also includes links to molecular biology databases of DNA/protein sequences and 3-D structure data.

The database Internet Grateful Med (http://igm.nIm.nih. gov/) provides an interface with a slightly different look and feel. Its one search screen offers more options than PubMed's simple search option, but is still easy to use. The same interface can be used to search 14 other databases, including resources on AIDS, bioethics, chemistry, the health care system, the history of medicine, population information, space life sciences and toxicology. The databases, many with identifiers ending in "... LINE", can also be accessed through many university library sites.

The NLM also sponsors the National Network of Libraries of Medicine (http://www.nnIm.nlm.nih.gov/) with the express purpose of making biomedical information available throughout the US. There's a toll-free number to call if you don't have access to an adequate library nearby. The network itself provides some document delivery services; there's also a page listing commercial providers (http:// www.nnlm.nlm.nih.gov/pnr/docsupp/).

The flagship database of the National Agricultural Library (NAL) (http://www.nalusda.gov/) is AGRICOLA. It contains citations on all disciplines related to agriculture, including animal and veterinary sciences, entomology, plant sciences, forestry, aquaculture and fisheries, farming and farming systems, agricultural economics, extension and education, food and human nutrition, and earth and environmental sciences. The database is divided into two subsets. One (Books, Etc.) describes holdings of the National Agricultural Library itself and includes audiovisual and other materials as well as bound volumes. The other (Articles, Etc.) is a general index of journal citations, together with book chapters, reports and reprints. The NAL provides access to a number of databases in addition to AGRICOLA, including several relating to nutrition.

The era of the World Wide Web has changed the very definition of a library. Many sites calling themselves by that name have no bricks-and-mortar component at all. The important thing is to verify the provenance of the information before using it, because after all, anyone can put up a Web site. One useful library-type site belongs to the publisher of the Physician's Desk Reference (PDR). PDR.net (http:// www.pdr.net/) offers free access to a number of databases and to several full-text journals: Contemporary OB/Gyn, Contemporary Pediatrics, Contemporary Urology, IM: Internal Medicine, Medical Economics and Patient Care. Physicians can also register for online access to the PDR.

It's worth learning to use online library resources now. Not only will it help you be more efficient, but it will also become increasingly important in your work as time goes on. The demand for immediate access to information, advances in the necessary hardware and software and the ability to provide additional services electronically at a reasonable price all point toward the growing importance of online research. 